\title{
Efficiency in the governance of the Covid- 19 pandemic: political and territorial factors
}

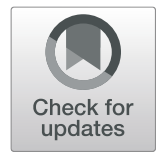

Pedro-José Martínez-Córdoba ${ }^{1 *}$ (D) Bernardino Benito ${ }^{1}$ and Isabel-María García-Sánchez²

\begin{abstract}
Background: The pandemic generated by Covid-19 has changed the way of life of citizens around the world in a short time, affecting all areas of society directly or indirectly, which is facing a global health crisis with different national responses implemented by governments. Several months into the pandemic, the first after-effects of Covid-19 are beginning to be felt by citizens, who are questioning the management carried out so far. In order to improve the performance of governmental decisions to reduce the impact of the pandemic during the coming months, we calculated the levels of efficiency in the management of health resources. In addition, we identify some country characteristics that may condition efficient management.

Results: We obtained significant differences according to the geographical location of the country, with European and American countries being less efficient than Asian and African countries. Likewise, we can affirm that greater freedom of expression, a higher median age and an unstable economy and labor market reduce efficiency. However, female leadership of the government and greater compliance with the rule of law offer more efficient management, as do countries that derive more revenues from tourism.

Conclusions: These results provide an opportunity for political leaders to reflect on their management during these months of the pandemic in order to identify mistakes and improve the implementation of effective measures. It has been shown that using more resources does not mean managing better; therefore, policymakers need to pay special attention to the use of resources, taking into account the budgetary constraints of the public sector.
\end{abstract}

Keywords: Covid-19, Efficiency, Pandemic governance, Global crisis, Economic impacts, Undesirable factors

\section{Introduction}

On March 11, 2020, the World Health Organization (WHO) declared the disease caused by the coronavirus SARS-CoV-2, better known as Covid-19, to be a pandemic. Since then, several months later and with more than 100 million people infected and 2,2 million dead (by early February 2021), the world and its inhabitants have experienced events unusual for their time. With the fear of a new economic recession and its implications, in addition to the foreseeable waves of infected

\footnotetext{
* Correspondence: pedrojose.martinez3@um.es

'Department of Accounting and Finance, Faculty of Economics and Business, Regional Campus of International Excellence "Campus Mare Nostrum", University of Murcia, 30100 Murcia, Spain

Full list of author information is available at the end of the article
}

people, an efficient management is required, capable of dealing with everything that exists and is about to arrive.

The characteristics of the Covid-19 pandemic, due to its severity, immediacy and complexity, have highlighted the weaknesses of governments in solving this crisis. Zoonotic diseases (such as that caused by Covid-19) represent a threat to life in society, with the possibility of causing a serious disruption to the world economy, a global event whose response is national and depends on the behavior patterns of citizens.

The socio-economic effects of Covid-19 are many and diverse, individually and collectively damaging people and the economy, and appropriate management is needed to resolve this situation [34]. Covid-19 is a challenge in terms of public health that affects all areas of 
life, where public managers responsible for solving this crisis must manage carefully and proactively the available resources in order to avoid risks and reduce the impact of the pandemic.

Effective management, able to take decisive action based on scientific knowledge rather than political opportunity, can explain much of the success of the response to Covid-19. Coordination, resource availability and political accountability can contribute to this goal, although many of the decisions adopted during the current pandemic have focused on political and economic considerations, and have left aside public health aspects [20].

In this sense, it is difficult to understand the different responses that governments have adopted to the same situation. Indeed, questions related to the governance of the pandemic arise, such as: Which territories have better managed health resources? Does political ideology influence the management of the pandemic? Has the governance of the pandemic been efficient? Thus, we propose three dimensions - Territory, Politics and Governance - interrelated with the efficient management of the pandemic [16], which may explain the differences between countries.

This research aims to understand the efficiency in the management of health resources to cope with the pandemic. Furthermore, we identify the impact of the country's characteristics (territorial, political, governance, sociodemographic and economic) that can condition the transmission of the virus, and consequently efficient management. Taking into account the volatility of the pandemic, the availability of information and the methodological changes that make it difficult to obtain data, we conducted an analysis that allows us to obtain the levels of efficiency for 155 countries along with results capable of contributing to improving the management of the pandemic over the coming months and years.

\section{Theoretical framework}

The need to find solutions to an unusual situation that affects all aspects of life has served to unite academia around Covid-19. In fact, as of January 1, 2021, in the main collection of the Web of Science we located 63,708 results when searching for the term "Covid-19", among which 32,782 are articles, which shows the relevance of the problem in just a few months. We reviewed some publications related to the management of Covid-19 and its impact on social, economic, and political areas. Below we highlight the most relevant aspects related to policy, pandemic governance and territory, as well as research related to efficiency in health management.

\section{Literature in times of pandemic}

The Covid-19 pandemic has shown how a health crisis can cause unprecedented damage worldwide. Other tragic events such as climate change or localized catastrophes allow for a greater response capacity, while the dimensions of this pandemic are yet to be discovered [21]. Some effects are already visible with the paralysis of economic activity, which represents a serious risk to the general and socioeconomic well-being of people [33].

The trade-off between economics and health has led to an important debate on how to take the most effective measures to curb the impact of the pandemic. The intensity and speed of the economic shock, highly visible in the loss of employment, and the severity of the economic contraction in relation to the spread of the virus have been the first consequences. All this has led to economic uncertainty never before seen on a global scale, which will make a rapid and complete recovery difficult [2].

Thus, differences in economic forecasts are related to the response capacity implemented by governments, as well as their exposure to international transmission of the virus, especially those most dependent on tourism. It is expected that governments with better performance in managing the crisis will also do so in economic terms, i.e., good health management of the pandemic is profitable for the country's society and economy [30].

In this regard, the speed and nature of post-Covid-19 economic recovery will be hampered by government actions to curb the pandemic, such as numerous disruptions in supply chains as a result of confinement and the reduction in demand due to decreased activity to avoid contracting the disease [44]. Consequently, it is necessary to diversify economic activities and reduce dependence on specific sectors to mitigate the impact of similar situations that may occur in the near future; in addition, investment in health infrastructure to deal with infectious diseases and progress in information and communication technologies is needed if pre-pandemic levels of growth and well-being are to be achieved [35].

The measures implemented to halt the spread of the virus have not had the same result in all countries [5], nor even within the same territory. The economic conditions of the population to cope with the health measures represent a relevant difference. Thus, citizens with inadequate housing, high rates of poverty or unemployment have a higher risk of death from Covid-19, even among the youngest population [22]. In the case of Italy, the first Western country to be severely punished by the pandemic, the reduction of mobility has been transcendental in the impact of the pandemic, with citizens with higher economic levels being more compliant, as they do not have to leave their homes to obtain resources [6]. 


\section{Political}

In addition, public leadership, not only political but also health-related, is presented as a key element in improving the management of the pandemic [19]. Leaders must be institutionally prepared for change and open to public-private collaboration to improve health management. These changes must be coupled with greater transparency in public health decisions, ensuring that science is not overridden by ideology, even when politically motivated [38]. In this sense, countries led by women tend to listen to and trust more the recommendations of science. Traditionally female characteristics, such as empathy, compassion and caring, have led to more effective responses to Covid-19 [37], improving governance in times of the pandemic.

In democratic systems, government legitimacy is an indispensable condition for maintaining political capacity and credibility. In times of crisis, citizens rely on government for credible information to guide their individual behavior [25]. Although ideological differences during the pandemic months have not had a significant impact on policy decisions, an early response has great advantages over a strict delay, i.e., early and flexible actions to contain the virus have better results than late and severe ones [40].

Notwithstanding the above, in some prominent countries the implementation of measures has been conditioned by the ideology of the rulers. For example, in the United States, Republicans are not as keen on following orders of social distancing as Democrats, the latter being more inclined to maintain recommended distances for the population and to comply with mobility restrictions [36]. In the case of Spain, and after the first wave of contagion, citizens are directing their preferences towards technocratic governments with strong leadership, given that the diversity of political opinions has not translated into the containment of the pandemic [3].

\section{Governance of pandemics}

The public sector faces complex problems in an increasingly turbulent social environment, having to manage uncertain and unpredictable scenarios. At the same time, it tries to solve these problems under pressure and without sufficient knowledge of their cause and effect. This requires political leaders to improve their responsiveness by designing, combining and executing sound governance strategies [4].

One of these problems has to do with pandemic diseases, which are capable of undermining even the best pre-established plans, due to their unprecedented characteristics and divergent requirements for their solution, irrespective of each government's forecasts. In this regard, governments face several important constraints in the governance of the pandemic, in particular with the uncertainty of citizens about the adverse consequences of the pandemic [10].

In this sense, the challenges posed by the governance of pandemics are not simply technical, but adequate government management must also take into account socio-political issues as well as the media projection of the events. A rational scientific approach to the management of pandemics is insufficient in the current sociodemographic and globalised context, and a sociopolitical mix of science, culture and public perceptions is needed for the development of public health policies [7]. Effective pandemic management requires an adaptive (taking into account the unprecedented character of the events) learning approach by governments, as well as a combination of knowledge of public health, epidemiology and socio-political factors, where trust in institutions, leadership or governance can be key elements [24].

Thus, the exercise of adequate governance can determine the outcomes of pandemic disease management. In the case of Human Immunodeficiency Virus (HIV), it has been shown that inadequate governance is associated with a higher prevalence of the disease, while it has been found that as governance improves, fewer women die in childbirth, there are more doctors per inhabitant, there is better access to clean water and life expectancy increases [32]. Furthermore, citizens' trust in government, as well as compliance with imposed rules and acceptance of new norms and values, is fundamental to the implementation of valid pandemic governance solutions, since government recommendations will be subject to frequent reformulations that may test the population's understanding and comprehension [4].

Predictive pandemic governance models provide robust and reliable evidence for decision-making. It is easy to think, therefore, that such models yield firm and reliable evidence, although during the swine flu pandemic in 2009, the weakness of the evidence formulated in the prediction was noted. Indeed, as time passed and cases were reported, the following questions were asked: Was a pandemic alert necessary? Why did governments spend a significant amount of money on vaccines and antiviral stockpiles that were never used and have now expired? [31]. Nevertheless, predictive models must be seen as a form of technical rationality in the broader context of governance [14]. Hence the timeliness of our study, in the sense that the results obtained can help governments in their investment decisions in the face of possible health pandemics that are likely to occur in the future.

Another important aspect of improving the speed and efficiency of pandemic governance is to learn from the past and adapt institutions to the new reality. A good example of this is the case of South Korea in the 
management of Middle East Respiratory Syndrome (MERS) in 2015, where after overcoming the pandemic they implemented new policies and institutional changes in anticipation of future pandemics, which has favoured the governance of the new coronavirus (Covid-19) with the early introduction of effective measures [38].

\section{Territory}

The Covid-19 pandemic became relevant in China in early 2020, and in March 2020 the world was confined without knowing how to deal with an unprecedented situation that was spreading out of control. It has been shown that the risk posed by lax health regulation in one locality can easily and quickly lead to a global health crisis (as has happened), and it is necessary to identify the geographical areas where the convergence of risk factors is most intense [9].

On the other hand, the supervening difficulties caused by a pandemic make it necessary to reflect on the appropriateness of whether public health governance and decision-making should be elevated to the global level. Subsidiarity provides a means in this regard to consider whether these public powers should be reallocated, even temporarily, although public health and economics are fundamental values within each State [15]. Subsidiarity is understood as the appropriate geographical distribution of power, arguing that powers should rest at the lowest possible level, unless it is more effective to allocate them at a higher level.

\section{Efficient health management}

The limited economic resources of the public sector, together with the citizens' demands for quality health care, force politicians to innovate in management to be more efficient. From this point of view, traditional management has been compared to New Public Management, without finding significant differences. However, numerous studies have shown greater efficiency in public health management than in private management [27]. For example, this is the case in Spain [1] or Germany, where privately owned healthcare centers show lower levels of efficiency, explained in part by a longer stay in these centers than in the public ones [26].

On the other hand, Hafidz et al. [23] suggest a series of recommendations to politicians with the aim of improving health services on both the supply and demand sides. On the supply side, it would be appropriate to optimize the workforce and the infrastructure, increase the quality of service and develop financial strategies; while on the demand side, financial barriers should be minimized, accessibility to health services should be increased and citizens' health habits should be changed. In addition, a system of hospital costs that allows an exhaustive control would mean taking more efficient decisions, thus improving the performance in health management [18]. However, in order to analyze health management in terms of efficiency, it is necessary to include exogenous factors that can strongly condition the provision of the service [11].

\section{Methods \\ Sample}

The speed and volatility of the pandemic has meant a complicated statistical process to homogenize data and provide valid and reliable information is needed. In order to analyze the level of efficiency in the management of the pandemic, it is necessary to have a certain number of comparable observations. The data offered by international organizations (World Bank, WHO, International Monetary Fund (IMF)) regarding the 237 countries of the world, are considered the most appropriate sources of information today. In addition, since the beginning of the pandemic, management has been led by national governments, which set the guidelines and standardize decisions at the country level. Therefore, the most appropriate units of analysis are the countries, although we have had to select those that report on the variables needed to calculate efficiency (see Table 1). Thus, once the countries with incomplete or erroneous data have been filtered out, the final sample was a set of 155 countries. Figures 1 and 2 show the countries included in the sample, with the exclusion of a small group that did not adequately report the necessary variables.

\section{Efficiency}

The research context determines the most appropriate technique for measuring efficiency. In our case, the characteristics of the public sector make it necessary to select a method that easily manages the production function and does not require data on the price of inputs or outputs, which is difficult to obtain in public services [41]. Among the most commonly used techniques, nonparametric (Data Envelopment Analysis -DEA, Free Disposable Hull and Order-m) and parametric (Stochastic Frontier Analysis) methods are the most used, with DEA being the most appropriate for calculating efficiency in the public sector environment, and more specifically in health care $[23,28,39]$. The objective of DEA is to obtain a relative efficiency level by means of linear programming problems, forming a frontier (envelope) that incorporates all the efficient Decision-Making Units (DMUs) (best input-output ratio) and their linear combinations, while placing the rest of the DMUs with values lower than the unit as inefficient.

To calculate the levels of efficiency with DEA, the inputs and outputs must be selected, and these are will be determined by the research objective. In our case, to 
Table 1 Description and descriptive statistics of the inputs, outputs, efficiency and environmental variables

\begin{tabular}{|c|c|c|c|c|c|c|}
\hline Variable & Description & Min & Mean & Median & Max & $\begin{array}{l}\text { Standard } \\
\text { deviation }\end{array}$ \\
\hline \multicolumn{7}{|l|}{ Inputs } \\
\hline Physicians & Total number of physicians per thousand inhabitants ${ }^{a}$ & 0.0140 & 1.9042 & 1.6090 & 7.1201 & 1.6125 \\
\hline Nurses & $\begin{array}{l}\text { Total number of nurses, midwives and other associated personnel per } \\
\text { thousand inhabitants }\end{array}$ & 0.0737 & 4.5672 & 2.9460 & 19.4614 & 4.3775 \\
\hline Hospital beds & Beds available in public and private hospitals per thousand inhabitants ${ }^{a}$ & 0.1000 & 2.8419 & 2.2000 & 13.4000 & 2.3871 \\
\hline Health expenditure & Level of current health expenditure expressed as a percentage of GDPa & 1.1812 & 6.5678 & 6.4294 & 17.0613 & 2.5149 \\
\hline \multicolumn{7}{|l|}{ Outputs } \\
\hline Cases confirmed & $\begin{array}{l}\text { Total number of confirmed cases of Covid-19 per thousand inhabitants } \\
\text { as February } 1,2021^{\mathrm{b}}\end{array}$ & 0.0088 & 20.5396 & 11.7416 & 92.5357 & 22.7485 \\
\hline Death rate & $\begin{array}{l}\text { Total number of deaths with Covid-19 per thousand confirmed cases as } \\
\text { February } 1,2021^{\mathrm{b}}\end{array}$ & 0.4871 & 20.5774 & 17.7672 & 85.1128 & 12.9607 \\
\hline \multicolumn{7}{|l|}{ Dependent variable } \\
\hline Efficiency & Own elaboration from DEA technique & 0.6018 & 0.8965 & 0.9399 & 1.0000 & 0.1092 \\
\hline \multicolumn{7}{|l|}{ Environmental variables } \\
\hline Europe & $\begin{array}{l}\text { Dummy variable that takes the value } 1 \text { if the country belongs to the } \\
\text { European region established by the } \mathrm{WHO} \text { and } 0 \text { otherwise }\end{array}$ & 0.0000 & 0.2968 & 0.0000 & 1.0000 & 0.4583 \\
\hline Americas & $\begin{array}{l}\text { Dummy variable that takes the value } 1 \text { if the country belongs to the } \\
\text { American region established by the } \mathrm{WHO} \text { and } 0 \text { otherwise }\end{array}$ & 0.0000 & 0.1871 & 0.0000 & 1.0000 & 0.3913 \\
\hline Asia & $\begin{array}{l}\text { Dummy variable that takes the value } 1 \text { if the country belongs to the } \\
\text { regions of South-East Asia and Western Pacific established by the WHO } \\
\text { and } 0 \text { otherwise }\end{array}$ & 0.0000 & 0.1226 & 0.0000 & 1.0000 & 0.3290 \\
\hline Africa & $\begin{array}{l}\text { Dummy variable that takes the value } 1 \text { if the country belongs to the } \\
\text { regions of Africa and Eastern Mediterranean established by the WHO } \\
\text { and } 0 \text { otherwise }\end{array}$ & 0.0000 & 0.3935 & 0.0000 & 1.0000 & 0.4901 \\
\hline Gender & $\begin{array}{l}\text { Dummy variable that takes the value } 1 \text { if the government leader is a } \\
\text { woman and } 0 \text { if it is a } \operatorname{man}^{c}\end{array}$ & 0.0000 & 0.1032 & 0.0000 & 1.0000 & 0.3052 \\
\hline Ideology & $\begin{array}{l}\text { Dummy variable that takes the value } 1 \text { if the government leader's } \\
\text { ideology is conservative and } 0 \text { if it is progressive } e^{c}\end{array}$ & 0.0000 & 0.4839 & 0.0000 & 1.0000 & 0.5014 \\
\hline Voice & $\begin{array}{l}\text { Quality of freedom of expression, association, media, and citizen } \\
\text { participation in the election of government, which takes values between } \\
0 \text { and } 100^{d}\end{array}$ & 2.4631 & 48.5238 & 45.3202 & 100.0000 & 28.4050 \\
\hline Rule of law & $\begin{array}{l}\text { Society's compliance with the rule of law, which takes values between } \\
0 \text { and } 100^{d}\end{array}$ & 0.4808 & 48.3468 & 46.1538 & 100.0000 & 28.6079 \\
\hline Median age & Median age of the population ${ }^{f}$ & 15.1510 & 30.5919 & 30.2620 & 48.3580 & 9.3129 \\
\hline GDP & $\begin{array}{l}\text { Forecast year-on-year change in gross domestic product at constant } \\
\text { prices as a percentage for } 2019^{\text {e }}\end{array}$ & -35.0000 & 2.5109 & 2.3350 & 9.8900 & 4.1384 \\
\hline Tourism & $\begin{array}{l}\text { Income from international tourism as a percentage of total exports in } \\
\text { goods and services }{ }^{a}\end{array}$ & 0.1888 & 13.7942 & 7.7834 & 85.2048 & 16.4688 \\
\hline Unemployment & Unemployment rate forecast for $2019^{e}$ & 0.2950 & 7.1966 & 7.1966 & 28.7000 & 3.7324 \\
\hline
\end{tabular}

\footnotetext{
Data from https://data.worldbank.org/indicator?tab=all Accessed February, 2021

${ }^{\mathrm{b}}$ Data from https://covid19.who.int/table Accessed February, 2021

'Own elaboration after consulting web information about the country

${ }^{\mathrm{d} D a t a}$ from http://info.worldbank.org/governance/wgi/ Accessed February, 2021

eData from https://www.imf.org/en/Publications/WEO/weo-database/2020/October Accessed February, 2021

fData from https://population.un.org/wpp/Download/Standard/Population/ Accessed July, 2021
}

determine the efficiency of pandemic management, the inputs refer to the resources available to manage a health crisis of these characteristics, and the outputs to its direct consequences. Thus, following the most recent literature analyzing efficiency in the health sector $[17$,
29], the selected inputs are the available physicians (Physicians) and nurses (Nurses), the number of hospital beds (Hospital beds) and the current expenditure on health care (Health expenditure), while the number of people infected by Covid-19 (Cases confirmed) and the number 


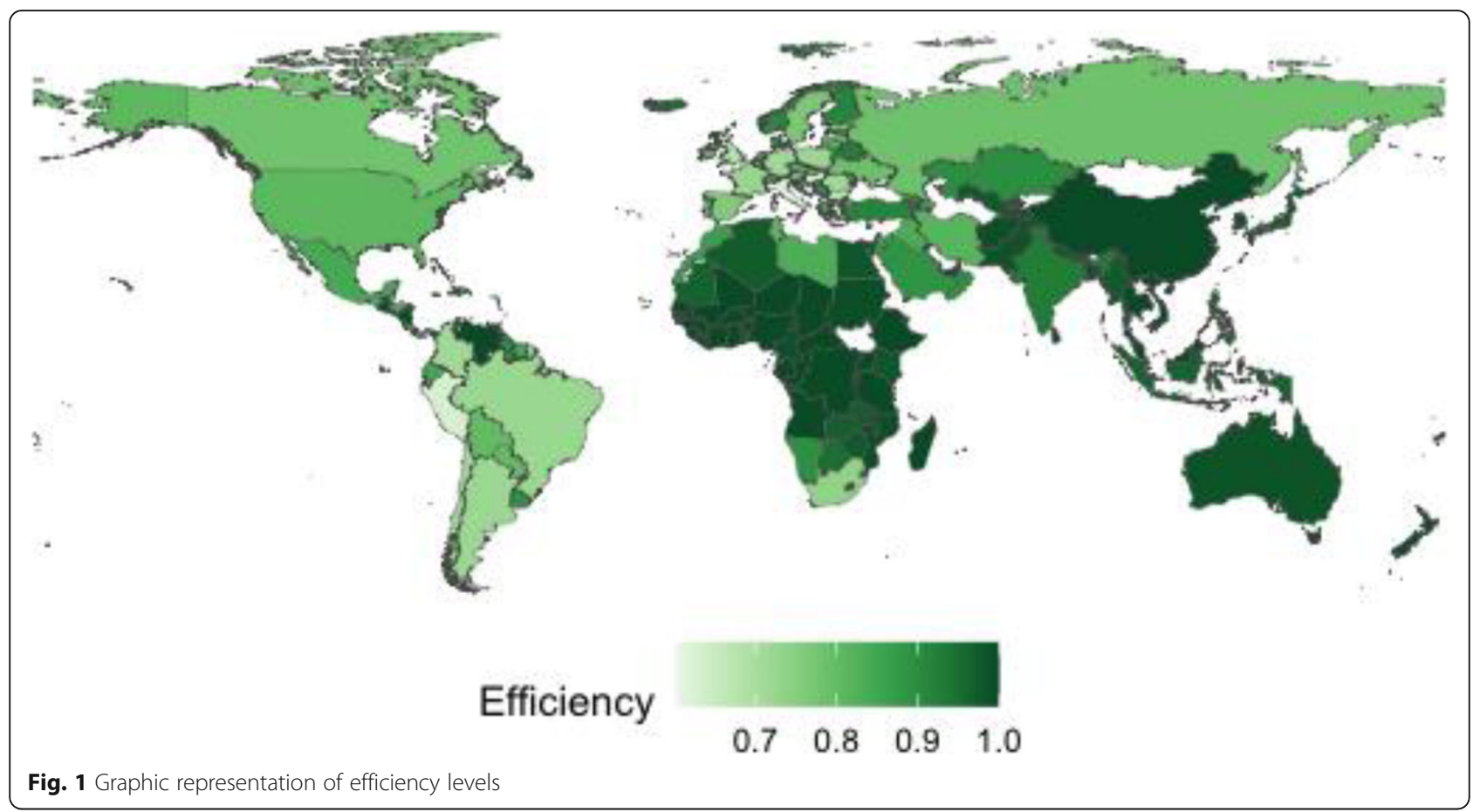

of deaths (Death rate) form the outputs. Table 1 explains each input and output in more detail, as well as the sources of information and descriptive statistics.

With the R-Studio software and the deaR package [8] we have obtained the efficiency levels for each country. DEA allows us to select the orientation of the model between input, when the objective is to minimize the resources employed (inputs) while maintaining constant the results (outputs), or output, when the aim is to maximize the results (outputs) while maintaining the resources (inputs). In our case, it could be interesting to minimize the vector of inputs (Physicians, Nurses, Hospital beds and Health expenditure) or to maximize the vector of outputs (Cases confirmed and Death rate). However, what we intend in our research is to design a model that allows us to maintain or increase the vector

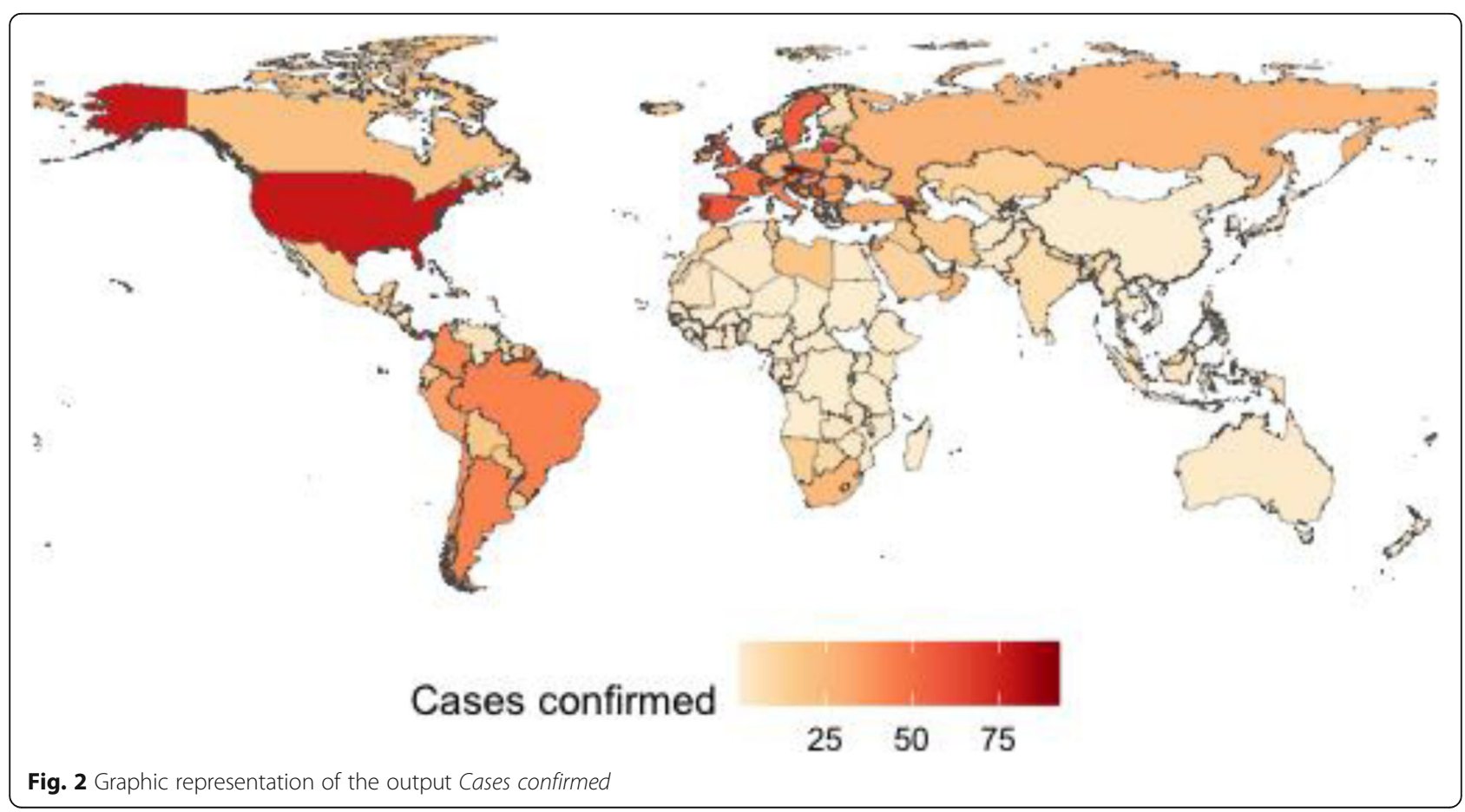


of inputs as far as possible and incorporate a vector of undesired outputs. Thus, we opt for the output orientation according to the model proposed by Seiford and Zhu [42], which reduces the undesired outputs. In addition, we selected variable returns to scale (VRS) due to the differences in the size of the DMUs, where different scales of production can be developed.

\section{Environmental variables}

Following the literature reviewed in the previous section (Theoretical framework), and in order to understand the characteristics of the countries that can influence the efficient management of the Covid-19 pandemic, we have selected variables representative of territory (Europe, America, Asia and Africa), politics (Gender and Ideology) and governance (Voice and Rule of law) of each country, as well as a set of control variables related to demographics (Median age) and economics (GDP, Tourism and Unemployment).

The variables Europe, Americas, Asia and Africa reflect the health regions established by the WHO. Gender represents the gender of the national government leader, which takes the value 1 if female and 0 for male. Ideology takes the value 1 for conservative rulers and 0 for progressive ones. Among the governance indicators we have selected those directly related to the management of the Covid-19 pandemic (Voice and Rule of law). Voice indicates freedom of expression, freedom of association and freedom of the media, and by choosing it we intend to show governments' commitment to transparency. Rule of law reflects compliance and respect for established rules. Median age represents the median age of the population. GDP is the percentage of year-on-year change in constant prices of Gross Domestic Product for 2019. Tourism is the percentage of exports in goods and services that represent the income obtained from international visitors. Unemployment is the unemployment rate in 2019. Table 1 specifies in more detail these variables, their descriptive statistics and the sources of information.

\section{Regression model}

To determine the impact of environmental variables on efficiency levels, we estimated the following regression model:

$$
\begin{aligned}
\hat{\delta}_{i}= & \alpha+\beta_{1} \text { Europe }_{i}+\beta_{2} \text { Americas }_{i}+\beta_{3} \text { Asia }_{i} \\
& +\beta_{4} \text { Africa }_{i}+\beta_{5} \text { Gender }_{i}+\beta_{6} \text { Ideology }_{i} \\
& +\beta_{7} \text { Voice }_{i}+\beta_{8} \text { Rule of law }_{i} \\
& +\beta_{9} \text { Median age }_{i}+\beta_{10} \text { GDP }_{i} \\
& +\beta_{11} \text { Tourism }_{i}+\beta_{12} \text { Unemployment }_{i}+\varepsilon_{i}
\end{aligned}
$$

where $\hat{\delta}_{i}$ represents the level of efficiency for each country; $\alpha$ is the constant of the model; $\beta_{j}$ are the coefficients of each variable; Europe, Americas, Asia, Africa, Gender, Ideology, Voice, Rule of law, Median age, GDP, Tourism and Unemployment, are the environmental variables; and $\varepsilon_{i}$ is the term of error.

The level of efficiency obtained with DEA, defined in the interval [0-1], conditions us to a truncated regression model as the best option to test the impact of environmental variables in a second stage [43]. We used $R$ Studio software with the package truncreg, which estimates model (1) for truncated Gaussian variables by maximum likelihood [12]. In addition, to avoid possible biases in the efficiency calculation, the separability condition [13] between inputs-outputs and environmental variables was tested, and the independence of these was confirmed.

The correlation matrix between inputs-outputs and environmental variables (Table 2) shows the significance of some of these variables, without compromising the validity of the level of efficiency or the regression model (1). For example, the indissoluble link between Physicians and Nurses, who complement each other in the healthcare activity, is essential to respond to the pandemic. In the case of the environmental variables, the significance is centered on aspects related to the geographical situation of the country (Europe, Americas, Asia and Africa), which we regress alternatively to avoid perfect multicollinearity.

Moreover, there may be correlations between the governance variables chosen, given that in countries with a strong Rule of law, the freedoms of expression, participation and communication (Voice) will be respected to a greater extent. In any case, taking into account the results of the control variables (see Table 4), the significant correlations shown in Table 2 do not condition the regression model (1).

\section{Discussion}

The efficiency levels are shown in Fig. 1, where we observe a significant difference between regions (Europe, Americas, Asia and Africa). The countries of Europe and Americas obtain on average lower values compared to those of Asia and Africa (see Table 3). We found that the less efficient countries, which are represented with a lighter color in Fig. 1, obtain a darker color in Fig. 2. Thus, the countries of Europe and the Americas show a higher average incidence (Cases confirmed) than the countries of Asia and Africa (see Table 3).

If the countries of Europe and the Americas have more resources (inputs) for pandemic management (see Table 3), their results should be more favorable. If this is not the case, we confirm the inefficiency in the management of health resources by these countries. These data could be explained by the capacity and information acquired in recent decades in Asian countries, as a result 
Table 2 Coefficient of correlation among inputs-outputs and environmental variables

\begin{tabular}{|c|c|c|c|c|c|c|c|c|c|c|c|}
\hline \multicolumn{12}{|l|}{ Inputs-Outputs } \\
\hline & Physicians & Nurses & $\begin{array}{l}\text { Hospital } \\
\text { beds }\end{array}$ & $\begin{array}{l}\text { Health } \\
\text { expenditure }\end{array}$ & $\begin{array}{l}\text { Cases } \\
\text { confirmed }\end{array}$ & & & & & & \\
\hline Nurses & $* * * 0.6773$ & 1.0000 & & & & & & & & & \\
\hline Hospital beds & $* * * 0.6526$ & $* * * 0.5949$ & 1.0000 & & & & & & & & \\
\hline $\begin{array}{l}\text { Health } \\
\text { expenditure }\end{array}$ & ${ }^{* * *} 0.4247$ & ${ }^{* * *} 0.5122$ & $* * * 0.3134$ & 1.0000 & & & & & & & \\
\hline $\begin{array}{l}\text { Cases } \\
\text { confirmed }\end{array}$ & $* * * 0.6539$ & $* * * 0.5337$ & $* * * 0.3989$ & $* * * 0.4089$ & 1.0000 & & & & & & \\
\hline Death rate & -0.1118 & -0.1779 & -0.1035 & 0.1340 & -0.1005 & & & & & & \\
\hline \multicolumn{12}{|c|}{ Environmental variables } \\
\hline & Europe & Americas & Asia & Africa & Gender & Ideology & Voice & $\begin{array}{l}\text { Rule of } \\
\text { law }\end{array}$ & $\begin{array}{l}\text { Median } \\
\text { age }\end{array}$ & GDP & Tourism \\
\hline Americas & $* *-0.3117$ & 1.0000 & & & & & & & & & \\
\hline Asia & -0.2428 & -0.1793 & 1.0000 & & & & & & & & \\
\hline Africa & $* * *-0.5233$ & $* * *-0.3865$ & $*^{*}-0.3011$ & 1.0000 & & & & & & & \\
\hline Gender & 0.2438 & -0.0540 & 0.0672 & -0.2299 & 1.0000 & & & & & & \\
\hline Ideology & 0.2470 & -0.0011 & -0.1257 & -0.1458 & 0.0110 & 1.0000 & & & & & \\
\hline Voice & $* * * 0.4351$ & 0.1725 & -0.0382 & $*^{* *}-0.5190$ & $* * 0.2962$ & 0.2188 & 1.0000 & & & & \\
\hline Rule of law & $* * * 0.4641$ & -0.0999 & 0.1354 & $* * *-0.4451$ & ${ }^{* *} 0.3003$ & 0.2596 & ${ }^{* * *} 0.7771$ & 1.0000 & & & \\
\hline Median age & $* * * 0.6808$ & 0.0007 & 0.1257 & $* * *-0.7216$ & ${ }^{*} 0.2652$ & 0.2350 & ***0.6245 & $* * * 0.7520$ & 1.0000 & & \\
\hline GDP & 0.0647 & *-0.2939 & 0.1290 & 0.0876 & 0.0474 & -0.0061 & -0.0009 & 0.0485 & -0.1038 & 1.0000 & \\
\hline Tourism & -0.1434 & 0.1676 & 0.0550 & -0.0366 & 0.0212 & -0.0033 & 0.0907 & 0.0142 & -0.0665 & 0.0710 & 1.0000 \\
\hline Unemployment & -0.0719 & 0.0246 & -0.2461 & 0.2128 & -0.1427 & -0.0858 & -0.0813 & -0.1811 & -0.1416 & -0.0652 & 0.1823 \\
\hline
\end{tabular}

Significance: ${ }^{* *} 1 \%,{ }^{*} 5 \%,{ }^{*} 10 \%$

of having effectively combated similar viruses (SARS and MERS-CoV). This is also the case in African countries, where they coexist with more uncontrolled diseases (Ebola and Malaria) that bestow on society a greater awareness of the extraordinary measures of health protection. Although the average efficiency of Africa is higher than that of Europe or Americas, some countries with economic and tourism solvency are below the average of the latter, as is the case of South Africa or Tunisia (0.7352 and 0.8093 , respectively).

Table 3 Average value of inputs, outputs and efficiency by geographical region

\begin{tabular}{lllll}
\hline & Europe & Americas & Asia & Africa \\
\hline Physicians & 3.6686 & 1.9782 & 1.6531 & 0.6167 \\
Nurses & 8.7961 & 3.4903 & 4.8689 & 1.7961 \\
Hospital beds & 5.1000 & 2.0552 & 3.2895 & 1.3738 \\
Health expenditure & 7.9148 & 7.2415 & 5.3588 & 5.6083 \\
Cases confirmed & 42.4300 & 22.2633 & 4.6839 & 8.1513 \\
Death rate & 18.6998 & 26.4294 & 16.8990 & 20.3571 \\
Efficiency & 0.8041 & 0.8481 & 0.9833 & 0.9622 \\
\hline
\end{tabular}

During the first weeks of the pandemic, political leaders in some countries such as the United States, Brazil and the United Kingdom denied the extent and consequences of the virus, implementing measures that favoured its spread. Thus, the efficiency levels obtained in these countries $(0.8084 ; 0.7215 ; 0.6809$, respectively) do not correspond to their economic, political and social characteristics. On the opposite side we find the Asian country where the virus originated (China), or those with more experience in pandemic management for having solved similar situations (South Korea), with very high levels of efficiency (0.9993; 0.9841, respectively). On the other hand, the arrival of Covid-19 in European countries such as Germany, France and Spain tested the response capacity of their governments, which tried to improve on the management carried out by the first western country affected by the pandemic (Italy); however, the results confirm that more and better can be done $(0.7153 ; 0.7248 ; 0.7567 ; 0.6018$, respectively).

The estimation of the regression model (1) provides information on the effect of environmental variables on efficiency levels (see Table 4). Taking into account the perfect multicollinearity that would exist if we regressed the variables Europe, Americas, Asia and Africa in the 


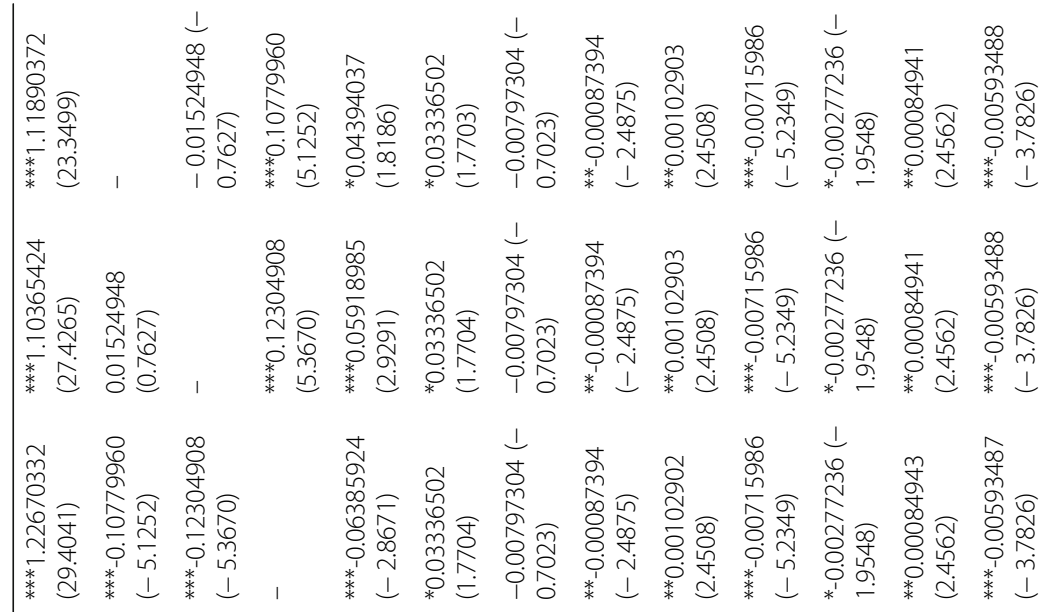

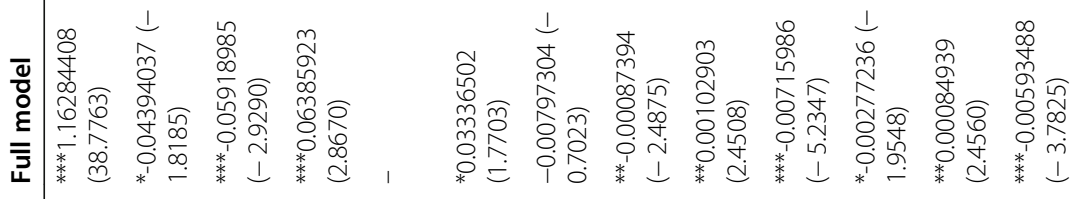


same model, we performed four regressions, alternatively omitting one of these variables and maintaining the rest (Full model), to secure more robust results. In addition, as a preliminary step to this complete model, we estimated the individual impact of the Territory, Politics and Governance variables on efficiency levels. These results allow us to know the relevance of each group of variables in the efficient management of the pandemic.

With respect to the geographical location of the country, the results of the regression model confirm the above. That is, countries located in Europe and the Americas show worse results in the efficiency of pandemic management than countries belonging to Asia and Africa. These results hold for the individual Territory estimate and for the Full model, so that the geographical impact of the country can be considered a relevant factor in the efficient management of the pandemic. There is a small deviation in the results when we estimate the model without the Asia variable, which appears to be less. These results should be interpreted with caution, knowing that the individual management of the pandemic by countries generates differences in the same geographical area.

Another relevant finding has been the effect of female leadership (Full model) on decision making during the pandemic (Gender). The qualities of women when facing risky situations, who show temperance and moderation in government actions, may be the cause of a more efficient management. With the available data, during the management of the pandemic we can affirm that countries led by women are more efficient than those led by men. However, there is still a gender gap in government leadership today, with only $10.32 \%$ of the countries in our sample being led by women. On the other hand, when faced with situations of these characteristics, governments have no margin for ideology, and are forced to implement technical and impartial decisions in favor of the common good. These political factors maintain their significance for both estimates (Politics and Full model).

Countries that are freer in the area of communication, expression or participation (Voice) will have citizens well informed and able to argue positions that diverge from those established by the government. Thus, political leaders should work more efficiently and effectively to gain the support of their citizens. However, the results indicate lower efficiency in pandemic management for countries with more Voice. In contrast, countries that are more respectful of their Rule of law achieve better results in the efficient management of the pandemic. Compliance with established regulations (home confinement, mobility restrictions, space capacity, among others) to curb the spread of the virus allows for the optimisation of available resources.
Focusing now on the control variables (demographics and economics), they maintain their significance and sign in all estimations, with the exception of the GDP variable, which loses its significance in the individual Politics and Governance estimation.

The virulence of the pandemic has been especially intense among the elderly (Median population) due to possible previous pathologies or a more deteriorated immune system. Thus, aging countries (older population) have needed more resources to deal with severe cases in this segment of the population, so limiting the response capacity of the health system. Consequently, an increase in the Median age implies a lower efficiency in the management of the pandemic, demonstrating that countries with an aging population have not been able to adapt their decisions to the peculiarities of their populations.

On the other hand, the intensity and speed with which events occurred during the first months of the pandemic, and which froze a large part of the productive activity for fear of health collapse, has caused an unprecedented shock to the economy. To this must be added the uncertainty generated in families, companies and governments by the lack of knowledge of the virus a counterproductive factor for the economy. We might expect those economies that are stronger and more solvent, i.e., those that are better prepared to face contingencies of this magnitude, to manage the pandemic better. Indeed, the results confirm this point, with countries with more vulnerable economies (higher GDP variation) reducing efficiency levels.

Countries that receive more revenue from tourism activities (Tourism) improve their efficiency. We understand that these countries strive to offer a good image that is capable of continuing to attract a high number of visitors, so proper management of the pandemic will improve their prestige and maintain the economic activity associated with this sector.

The labor market situation (Unemployment) is a good example of how families and households are financially able to withstand crisis situations. In this sense, high unemployment rates reduce people's autonomy, making them more vulnerable and dependent. Thus, countries with an unstable and poorly diversified labor market (higher unemployment rate) are less able to cope with the effects of the pandemic, and so efficiency deteriorates. This may condition management by governments, because not only the victims of Covid-19 should be attended to, but also those affected by the economic situation, which means diversifying efforts and reducing efficiency.

\section{Conclusions and policy implications}

Improving health management is a current priority for governments in view of the situation generated by 
Covid-19, which affects both people's health and the economy. The policies implemented to solve this pandemic are many and varied, depending on the governments of each country, and although facing the same problem, the responses have been different. Taking into account the evolution of the pandemic 11 months later, we thought it necessary to evaluate the health management carried out so far in order to better respond to the foreseeable waves of contagion and their effects.

To this end, we calculated the levels of efficiency in the management of health resources and estimated the impact of Territory, Politics and Governance characteristics controlled by demographic and economic variables of the country. We use DEA as the most appropriate technique to obtain efficiency with undesirable outputs (Cases confirmed and Death rate). We found that the countries that use more resources in the health system obtain worse results in the management of the pandemic. In particular, European and American countries are less efficient than Asian and African countries.

Thus, we confirm that the geographical situation of the country (Territory) as relevant factor for efficient management of the pandemic. With respect to Politics, female leadership of the government seems to incorporate aspects in management that improve efficiency. The Governance represent a fundamental element in solving the health crisis, greater freedom of expression, communication and citizen participation, as well as poor compliance with the rule of law, will hinder the efficient management of the pandemic. On the other hand, we can state that aging populations, vulnerable economies and an unstable labour market before the pandemic reduce efficiency, while countries that obtain more revenues from international tourism will strive to show a solvent image, thus improving their efficiency. In contrast, the ideology of the government leader do not have a significant effect.

These results provide an opportunity for political leaders to reflect on their management during these months of the pandemic in order to identify mistakes and improve the implementation of effective measures. It has been shown that using more resources does not mean managing better; therefore, policymakers need to pay special attention to the use of resources, taking into account the budgetary constraints of the public sector. Moreover, a very important aspect of efficiency is to learn from the past and not to make the same mistakes. Thus, experience in the governance of pandemics is a key factor, with those countries that have managed similar circumstances in the past being the ones that have obtained the best economic and social results.

Finally, the limitations of the research are centered on the volatility of the pandemic and the inadequate information due to methodological differences in data collection. In the coming months and years, when more and better information becomes available, it will be possible to analyse the management of the pandemic in a broader perspective and to identify the causes and effects in each country. Until then, the results of this research offer an opportunity for policy makers to reflect on their management and to try to improve many aspects before it is too late.

\section{Acknowledgements}

Not applicable.

\section{Authors' contributions}

Pedro-José Martínez-Córdoba: Conceptualization, methodology, software, validation, formal analysis, investigation, resources, data curation and writingoriginal draft preparation. Bernardino Benito: Conceptualization, formal analysis, writing-review and editing, visualization, supervision, project administration. Isabel-María García-Sánchez: Conceptualization, formal analysis, writingreview and editing, visualization, supervision, project administration. All authors read and approved the final manuscript.

\section{Authors' information}

Pedro-José Martínez-Córdoba has a research grant from the Spanish Ministry of Education, and is working at the University of Murcia, Spain. He has recently published in Waste Management, Evaluation and Program Planning and Local Government Studies.

Bernardino Benito is a professor of public sector accounting at the University of Murcia, Spain. His research interests focus on public administration, accountability and management, public finance, transparency, performance budgeting and cost of public services. He has recently published in, among other publications, Cities, Utilities Policy, Applied Economics, Local Government Studies, Public Choice and the Revista de Contabilidad-Spanish Accounting Review.

Isabel-María García-Sánchez is a professor in accounting at the University of Salamanca, Spain. Her research interests focus on public sector reforms, especially accountability and transparency in local public services; the private sector, corporate governance and corporate social responsibility. Her work has been published in journals, such as Central European Journal of Operations Research, Government Information Quarterly and Corporate Social Responsibility and Environmental Management.

\section{Funding}

Not applicable.

Availability of data and materials

Not applicable.

\section{Declarations}

Ethics approval and consent to participate Not applicable.

Consent for publication

Not applicable.

\section{Competing interests}

Not applicable.

\section{Author details}

${ }^{1}$ Department of Accounting and Finance, Faculty of Economics and Business, Regional Campus of International Excellence "Campus Mare Nostrum", University of Murcia, 30100 Murcia, Spain. ${ }^{2}$ Instituto Multidisciplinar de Empresa, Campus Miguel de Unamuno, Universidad de Salamanca, 37007 Salamanca, Spain 
Received: 14 April 2021 Accepted: 1 September 2021 Published online: 21 September 2021

\section{References}

1. Alonso JM, Clifton J, Díaz-Fuentes D. The impact of new public management on efficiency: an analysis of Madrid's hospitals. Health Policy 2015;119(3):333-40. https://doi.org/10.1016/j.healthpol.2014.12.001.

2. Altig D, Baker S, Barrero JM, Bloom N, Bunn P, Chen S, et al. Economic uncertainty before and during the COVID-19 pandemic. J Public Econ. 2020; 191:104274. https://doi.org/10.1016/j.jpubeco.2020.104274.

3. Amat F, Arenas A, Falcó-Gimeno A, Muñoz J. Pandemics meet democracy. Experimental evidence from the COVID-19 crisis in Spain. 2020. https://doi. org/10.31235/osf.io/dkusw.

4. Ansell C, Sørensen E, Torfing J. The COVID-19 pandemic as a game changer for public administration and leadership? The need for robust governance responses to turbulent problems. Public Manag Rev. 2020:1-12. https://doi. org/10.1080/14719037.2020.1820272.

5. Asongu SA, Diop S, Nnanna J. The geography of the effectiveness and consequences of Covid-19 measures: Global evidence. J Public Affairs. 2020: e2483. https://doi.org/10.1002/pa.2483.

6. Bonaccorsi G, Pierri F, Cinelli M, Flori A, Galeazzi A, Porcelli F, et al. Economic and social consequences of human mobility restrictions under COVID-19. Proc Natl Acad Sci. 2020;117(27):15530-5. https://doi.org/10.1073/pnas.2 007658117.

7. Carney T, Bennett B. Framing pandemic management: new governance, science or culture? Health Sociol Rev. 2014;23(2):136-47. https://doi.org/10.1 080/14461242.2014.11081968

8. Coll-Serrano, V., Bolos, V., \& Benitez Suarez, R. (2020). deaR: conventional and fuzzy data envelopment analysis. R package version 1.2.2. https://CRAN.Rproject.org $/$ package $=$ deaR

9. Connolly C, Keil R, Ali SH. Extended urbanisation and the spatialities of infectious disease: demographic change, infrastructure and governance. Urban Stud. 2021;58(2):245-63. https://doi.org/10.1177/0042098020910873.

10. Cook AH, Cohen DB. Pandemic disease: a past and future challenge to governance in the United States. Rev Policy Res. 2008;25(5):449-71. https:// doi.org/10.1111/j.1541-1338.2008.00346.x.

11. Cordero-Ferrera JM, Crespo-Cebada E, Murillo-Zamorano LR. Measuring technical efficiency in primary health care: the effect of exogenous variables on results. J Med Syst. 2011;35(4):545-54. https://doi.org/10.1007/s10916009-9390-6.

12. Croissant, Y., \& Zeileis, A. (2018). Truncreg: truncated Gaussian regression models. R package version 0.2-5. https://CRAN.R-project.org/package= truncreg

13. Daraio C, Simar L, Wilson PW. Central limit theorems for conditional efficiency measures and tests of the 'separability 'condition in nonparametric, two-stage models of production. Econ J. 2018;21(2):170-91. https://doi.org/10.1111/ectj.12103.

14. Delaney A, Kitchin R. Progress and prospects for data-driven coordinated management and emergency response: the case of Ireland: Territory, Politics, Governance; 2020. p. 1-16. https://doi.org/10.1080/21622671.2020.1 805355

15. Dobbs M. National Governance of public health responses in a pandemic? Eur J Risk Regul. 2020;11(2):240-8. https://doi.org/10.1017/err.2020.39.

16. Dodds K, Castan Broto V, Detterbeck K, Jones M, Mamadouh V, Ramutsindela M, et al. The COVID-19 pandemic: territorial, political and governance dimensions of the crisis. Territory, Politics, Governance. 2020; 8(3):289-98. https://doi.org/10.1080/21622671.2020.1771022.

17. Franco Miguel JL, Fullana Belda C, Cordero Ferrera JM, Polo C, Nuño-Solinís R. Efficiency in chronic illness care coordination: public-private collaboration models vs traditional management. BMC Health Services Res. 2020;20:1044 https://doi.org/10.1186/s12913-020-05894-z.

18. García-Cornejo B, Pérez-Méndez JA. Influence of cost systems on efficiency. An analysis of Spanish hospitals using public national databases. Revista de Contabilidad-Spanish Accounting Review. 2020;23(2):249-62. https://doi. org/10.6018/rcsar.365031.

19. Glenn J, Chaumont C, Dintrans PV. Public health leadership in the times of COVID-19: a comparative case study of three countries. Int J Public Leader. 2020;17(1):81-94. https://doi.org/10.1108/IJPL-08-2020-0082.

20. Goniewicz K, Khorram-Manesh A, Hertelendy AJ, Goniewicz M, Naylor K Burkle FM. Current response and management decisions of the European
Union to the COVID-19 outbreak: a review. Sustainability. 2020;12(9):3838. https://doi.org/10.3390/su12093838.

21. Goodell JW. COVID-19 and finance: agendas for future research. Financ Res Lett. 2020:35:101512. https://doi.org/10.1016/j.frl.2020.101512.

22. Goutte $S$, Péran $T$, Porcher $T$. The role of economic structural factors in determining pandemic mortality rates: evidence from the COVID-19 outbreak in France. Res Int Bus Financ. 2020;54:101281. https://doi.org/10.1 016/j.ribaf.2020.101281.

23. Hafidz F, Ensor T, Tubeuf S. Efficiency measurement in health facilities: a systematic review in low-and middle-income countries. Appl Health Econ Health Policy. 2018;16(4):465-80. https://doi.org/10.1007/s40258-018-0385-7.

24. Hale, T., Angrist, N., Kira, B., Goldszmidt, R. G., Petherick, A., \& Phillips, T. (2020). Pandemic Governance Requires Understanding Socioeconomic Variation in Government and Citizen Responses to COVID-19. Available at SSRN: https://ssrn.com/abstract=3641927

25. Hartley K, Jarvis DS. Policymaking in a low-trust state: legitimacy, state capacity, and responses to COVID-19 in Hong Kong. Polic Soc. 2020;39(3): 403-23. https://doi.org/10.1080/14494035.2020.1783791.

26. Herr A. Cost and technical efficiency of German hospitals: does ownership matter? Health Econ. 2008;17(9):1057-71. https://doi.org/10.1002/hec.1388.

27. Hollingsworth $B$. The measurement of efficiency and productivity of health care delivery. Health Econ. 2008;17(10):1107-28. https://doi.org/10.1002/ hec.1391.

28. Hollingsworth B, Dawson PJ, Maniadakis N. Efficiency measurement of health care: a review of non-parametric methods and applications. Health Care Manag Sci. 1999;2(3):161-72. https://doi.org/10.1023/A:1019087828488.

29. Kohl S, Schoenfelder J, Fügener A, Brunner JO. The use of data envelopment analysis (DEA) in healthcare with a focus on hospitals. Health Care Manag Sci. 2019;22(2):245-86. https:/doi.org/10.1007/s10729-018-9436-8.

30. König M, Winkler A. COVID-19 and economic growth: does good government performance pay off? Intereconomics. 2020;55(4):224-31. https://doi.org/10.1007/s10272-020-0906-0.

31. Mansnerus E. Using model-based evidence in the governance of pandemics. Sociol Health IIIness. 2013;35(2):280-91. https://doi.org/10.1111/ j.1467-9566.2012.01540.x

32. Menon-Johansson AS. Good governance and good health: the role of societal structures in the human immunodeficiency virus pandemic. BMC Int Health Hum Rights. 2005;5(1):1-10. https://doi.org/10.1186/1472-698X5-4

33. Mofijur M, Fattah IR, Alam MA, Islam AS, Ong HC, Rahman SA, et al. Impact of COVID-19 on the social, economic, environmental and energy domains: lessons learnt from a global pandemic. Sustain Product Consum. 2020;26: 343-59. https://doi.org/10.1016/j.spc.2020.10.016

34. Nicola M, Alsafi Z, Sohrabi C, Kerwan A, Al-Jabir A, losifidis C, et al. The socio-economic implications of the coronavirus pandemic (COVID-19): a review. International Journal of Surgery (London, England). 2020;78:185-93. https://doi.org/10.1016/j.ijsu.2020.04.018.

35. Ozili, P. K. (2020). COVID-19 pandemic and economic crisis: the Nigerian experience and structural causes. Available at SSRN: https://ssrn.com/ abstract $=3567419$ or $10.2139 /$ ssrn.3567419

36. Painter, M., \& Qiu, T. (2020). Political beliefs affect compliance with covid-19 social distancing orders. Available at SSRN: https://ssrn.com/abstract= 3569098 or $10.2139 /$ ssin. 3569098

37. Panayiotou A. Teaching leadership the "day after", with care. Gender Manag 2020;35(7/8):629-37. https://doi.org/10.1108/GM-07-2020-0223.

38. Park J, Chung E. Learning from past pandemic governance: early response and public-private partnerships in testing of COVID-19 in South Korea. World Dev. 2021;137:105198. https://doi.org/10.1016/j.worlddev.2020.105198.

39. Pelone F, Kringos DS, Romaniello A, Archibugi M, Salsiri C, Ricciardi W. Primary care efficiency measurement using data envelopment analysis: a systematic review. J Med Syst. 2015;39(1):156. https://doi.org/10.1007/s1091 6-014-0156-4

40. Plümper T, Neumayer E. Lockdown policies and the dynamics of the first wave of the Sars-CoV-2 pandemic in Europe. J Eur Public Policy. 2020:1-21. https://doi.org/10.1080/13501763.2020.1847170.

41. Ruggiero, J. (1996). On the measurement of technical efficiency in the public sector. Eur J Oper Res, 90(3), 553-565. https://doi.org/10.1016/03 77-2217(94)00346-7.

42. Seiford, L. M., \& Zhu, J. (2002). Modeling undesirable factors in efficiency evaluation. Eur J Oper Res, 142(1), 16-20. https://doi.org/10.1016/S0377-221 7(01)00293-4 
43. Simar L, Wilson PW. Estimation and inference in two-stage, semi-parametric models of production processes. J Econ. 2007;136(1):31-64. https://doi.org/1 0.1016/j.jeconom.2005.07.009.

44. Tisdell CA. Economic, social and political issues raised by the COVID-19 pandemic. Econ Anal Policy. 2020;68:17-28. https://doi.org/10.1016/j.eap.202 0.08.002.

\section{Publisher's Note}

Springer Nature remains neutral with regard to jurisdictional claims in published maps and institutional affiliations.

- fast, convenient online submission

- thorough peer review by experienced researchers in your field

- rapid publication on acceptance

- support for research data, including large and complex data types

- gold Open Access which fosters wider collaboration and increased citations

- maximum visibility for your research: over $100 \mathrm{M}$ website views per year

At BMC, research is always in progress. 